\title{
Specific components of prostanoid-signaling pathways are present in non-small cell lung cancer cells
}

\author{
MIHAELA KREUTZER $^{1 *}$, TANJA FAUTI $^{1 *}$, KERSTIN KADDATZ $^{1}$, CAROLA SEIFART $^{2}$, \\ ANDREAS NEUBAUER $^{2}$, HORST SCHWEER ${ }^{3}$, MARTIN KÖMHOFF ${ }^{3}$, \\ SABINE MÜLLER-BRÜSSELBACH ${ }^{1}$ and ROLF MÜLLER ${ }^{1}$ \\ ${ }^{1}$ Institute of Molecular Biology and Tumor Research (IMT), Philipps University, Emil-Mannkopff-Strasse 2, \\ D-35032 Marburg; Departments of ${ }^{2}$ Internal Medicine, ${ }^{3}$ Pediatrics, Philipps University, \\ Baldingerstr., D-35043 Marburg, Germany
}

Received January 12, 2007; Accepted March 16, 2007

\begin{abstract}
In the present study, we measured prostanoid synthesis and the expression of genes associated with prostanoid signaling in human non-small cell lung carcinoma (NSCLC) cell lines and in primary human tumors. Consistent with the proposed growth promoting role of $\mathrm{PGE}_{2}$, we found that NSCLC cell lines frequently co-expressed the genes encoding cyclooxygenase- 2 and the prostaglandin $\mathrm{E}_{2}\left(\mathrm{PGE}_{2}\right)$ receptors EP1, 2 and 4 concomitant with the synthesis of $\mathrm{PGE}_{2}$. In contrast, NSCLC cells did not synthesize appreciable amounts of prostaglandin $\mathrm{I}_{2}\left(\mathrm{PGI}_{2}\right.$, prostacyclin), lacked $\mathrm{PGI}_{2}$ synthase (PGIS) and did not express the gene coding for the $\mathrm{PGI}_{2}$ receptor IP at detectable levels. In agreement with this finding, PGIS mRNA levels were dramatically diminished in primary human tumor samples as compared to matched normal lung tissue. Finally, thromboxane $\mathrm{A}_{2}\left(\mathrm{TxA}_{2}\right)$ was synthesized in NSCLC cell lines, but transcription of the gene coding for the $\mathrm{TxA}_{2}$ receptor TP was not observed in these cells. In marked contrast, lung fibroblasts synthesized all three prostanoids and their receptors at high levels. While the observed expression patterns were consistent with the existence of autocrine/paracrine $\mathrm{PGE}_{2}$ signaling loops in NSCLC cells, $\mathrm{PGI}_{2}$ - and $\mathrm{TxA}_{2}$-mediated signals may play a role in tumor stroma cells.
\end{abstract}

Correspondence to: Dr Rolf Müller, Institute of Molecular Biology and Tumor Research (IMT), Philipps University, EmilMannkopff-Strasse 2, D-35032 Marburg, Germany

E-mail: rmueller@imt.uni-marburg.de

${ }^{*}$ Contributed equally

Key words: non-small cell lung cancer, cyclooxygenase-2, prostaglandin $\mathrm{E}_{2}$

\section{Introduction}

The cyclooxygenases (Cox-1, Cox-2) are rate-limiting enzymes in the synthesis of all prostanoids from arachidonic acid (1). Research in the past decade has clearly established Cox-2 as a crucial player in tumor growth and progression (2-4). Cyclooxygenases catalyze a two-step reaction that converts arachidonic acid to prostaglandin $\mathrm{H}_{2}\left(\mathrm{PGH}_{2}\right)$, which in turn serves as the precursor for the synthesis of the biologically active prostanoids $\mathrm{PGD}_{2}, \mathrm{PGE}_{2}, \mathrm{PGF}_{2}, \mathrm{PGI}_{2}$ (prostacyclin) and thromboxane $\mathrm{A}_{2}$ by specific prostanoid synthases (1). The prostanoids act as agonists of G-proteincoupled membrane receptors, termed DP, EP1 through EP4, FP, IP and TP, which in turn trigger multiple second messenger generating systems $(5,6)$. Several specific components of this prostanoid signaling network have been associated with oncogenesis, in particular $\mathrm{PGE}_{2}$ and its membrane receptors EP2, EP3 and EP4 (6). These conclusions are based on results obtained with knock-out mice as well as selective agonists or inhibitors (7-13). On the other hand, the role of $\mathrm{PGI}_{2}$ is controversial, as both tumor growth-promoting and inhibitory effects have been described (14-16). The role of other prostanoids is largely unclear, even though $\mathrm{TxA}_{2}$ has been reported to enhance tumor growth in mice (17). In human non-small cell lung carcinoma (NSCLC), expression of Cox-2 and prostaglandin $\mathrm{E}_{2}$ synthase (PGES) has been demonstrated in several studies (18), and there is strong evidence for a tumor-promoting role of Cox-2 and most likely $\mathrm{PGE}_{2}$ on these tumors (19-24). Thromboxane $\mathrm{A}_{2}$ synthase (TxAS) and prostaglandin $\mathrm{I}_{2}$ synthase (PGIS) expression in NSCLCs has been analyzed, but this study relied entirely on immunohistochemistry (25). We therefore sought to perform a systematic analysis of prostanoid synthesis and gene expression associated with prostanoid signaling in human NSCLCs.

\section{Materials and methods}

Cell culture. NSCLC cell lines were obtained from K. Havemann (Marburg). LLC1, WI38 and HEL cells were 
Table I. The primers and annealing conditions.

\begin{tabular}{|c|c|c|c|c|}
\hline Human genes & Sequence $5^{\prime} \rightarrow 3^{\prime}$ & $\begin{array}{l}\text { Length } \\
\text { (nt) }\end{array}$ & $\begin{array}{l}\text { Product } \\
\text { (bp) }\end{array}$ & $\begin{array}{l}\text { Annealing } \\
\text { temperature }\left({ }^{\circ} \mathrm{C}\right)\end{array}$ \\
\hline$\beta$-actin & $\begin{array}{l}\text { GATGATGATATCGCCGCGCTCGTCGTC } \\
\text { GTGCCTCAGGGCAGCGGACCGCTCA }\end{array}$ & $\begin{array}{l}24 \\
25\end{array}$ & 800 & $53-62$ \\
\hline$C O X-1$ & $\begin{array}{l}\text { GGTGGGGTGTTCTTCTTG } \\
\text { TCCСTCAACCССТСАТСTT }\end{array}$ & $\begin{array}{l}18 \\
19\end{array}$ & 1125 & 58 \\
\hline$C O X-2$ & $\begin{array}{l}\text { ССТTСТССААССТСТССТАС } \\
\text { AGGGGGTGCCAGTGATAGAG }\end{array}$ & $\begin{array}{l}20 \\
20\end{array}$ & 748 & 58 \\
\hline$m P G E S$ & $\begin{array}{l}\text { CACGCTGCTGGTCATCAAGA } \\
\text { TAGGTCACGGAGCGGATGG }\end{array}$ & $\begin{array}{l}20 \\
19\end{array}$ & 330 & 61 \\
\hline $\begin{array}{l}P G I S \\
(\mathrm{RT}-\mathrm{PCR}, \mathrm{qPCR})\end{array}$ & $\begin{array}{l}\text { AGGAGAAGCACGGTGACATC } \\
\text { GCAGCGCCTCAATTCCGTAA }\end{array}$ & $\begin{array}{l}20 \\
20\end{array}$ & 386 & 58 \\
\hline$T x A S$ & $\begin{array}{l}\text { GGTGCCCTGATGTCTGCTTT } \\
\text { TCTTGGCAGTCAGGGTTGGT }\end{array}$ & $\begin{array}{l}20 \\
20\end{array}$ & 686 & 56 \\
\hline$E P 1$ & $\begin{array}{l}\text { CCTCGTCCGCCTCGTCCATC } \\
\text { CGGGGGCAAGAGGCGAAGCA }\end{array}$ & $\begin{array}{l}20 \\
20\end{array}$ & 317 & 63 \\
\hline$E P 2$ & $\begin{array}{l}\text { GCTGCCGCTGCTGGACTATG } \\
\text { CAAGGAGCAGACGGCGAAGG }\end{array}$ & $\begin{array}{l}20 \\
20\end{array}$ & 328 & 63 \\
\hline EP3 & $\begin{array}{l}\text { CCCGCCTCAACCACTCCTAC } \\
\text { CCAGGAAGGCAAAGGCAGAG }\end{array}$ & $\begin{array}{l}20 \\
20\end{array}$ & 669 & 63 \\
\hline EP4 & $\begin{array}{l}\text { CCTCCTGAGAAAGACAGTGCT } \\
\text { AAGACACTCTCTGAGTCCT }\end{array}$ & $\begin{array}{l}21 \\
19\end{array}$ & 366 & 60 \\
\hline$I P$ & $\begin{array}{l}\text { AAATAACCAGTGGCCTGGC } \\
\text { TTGGGCCTCCTAAGTGGAC }\end{array}$ & $\begin{array}{l}19 \\
19\end{array}$ & 161 & 53 \\
\hline$T P$ & $\begin{array}{l}\text { TTCGCCGCCTCCTTCTGC } \\
\text { CGCCTCCTGCCCGTGGTA }\end{array}$ & $\begin{array}{l}18 \\
18\end{array}$ & 606 & 64 \\
\hline $\begin{array}{l}\text { L27 } \\
(\mathrm{qPCR})\end{array}$ & $\begin{array}{l}\text { TGATGGCACCTCAGATCGC } \\
\text { AGAGTACCTTGTGGGCATTAGG }\end{array}$ & $\begin{array}{l}19 \\
22\end{array}$ & 169 & 58 \\
\hline
\end{tabular}

purchased from the ATCC. NIH3T3 cells were provided by D. Lowy (NIH), and Line-1 (26) and other mouse lung adenoma lines by G. Stoner (Ohio State University). All cell lines were cultured in DMEM supplemented with $10 \%$ fetal bovine serum, $100 \mathrm{U} / \mathrm{ml}$ penicillin and $100 \mu \mathrm{g} / \mathrm{ml}$ streptomycin. Human bronchial epithelial cells (HBEPCs) were purchased from Promocell (Heidelberg, Germany) and cultured as suggested by the supplier. Cells were maintained at $37^{\circ} \mathrm{C}$ with $5 \% \mathrm{CO}_{2}$ in a humidified incubator.

RNA isolation. RNA was isolated by using the RNeasy ${ }^{\mathrm{TM}}$ kit (Qiagen, Hilden, Germany) following the manufacturer's protocol. Qia shredders (Qiagen) were used to break down genomic DNA of lysed cells.

Reverse transcriptase (RT-PCR) and real-time PCR ( $q P C R)$. cDNA was synthesized using $1 \mu \mathrm{g}$ of RNA, oligo(dT) primers and reverse transcriptase according to the manufacturer's protocol (Roche Diagnostics). RT-PCR was performed with Platinum Taq polymerase (Invitrogen, Karlsruhe, Germany). qPCR reactions were carried out with the Absolute QPCR
SYBR-Green mix (Abgene, Hamburg, Germany) at a primer concentration of $0.2 \mu \mathrm{M}$ in an Mx3000P Real-time PCR system (Stratagene, La Jolla, CA) for 45 cycles. Primers and annealing conditions were as described in Table I. For qPCR experiments, $L 27$ was used as the normalizer. Results were expressed as $\mathrm{Ct}$ values corrected for differences in $L 27$ expression (average $\mathrm{Ct}$ value for $L 27=20$ ).

Prostanoid analysis by GC/MS/MS analysis. For the determination of prostanoid release, $10^{6}$ cells were cultured on $6-\mathrm{cm}$ tissue culture dishes in $5 \mathrm{ml}$ of fresh DMEM $+10 \%$ fetal bovine serum for $24 \mathrm{~h}$. Samples were prepared as described (27) with minor modifications. Briefly, cell culture supernatants were spiked with $\sim 10 \mathrm{ng}$ of deuterated internal standards, and the solvent was removed. The methoxime was obtained through reaction with an O-methylhydroxylamine hydrochloride-acetate buffer. After acidification to $\mathrm{pH} 3.5$, prostanoid derivatives were extracted, and the pentafluorobenzylesters were formed. Samples were purified by thinlayer chromatography, and two broad zones with $R_{v}$ 0.03-0.39 and $0.4-0.8$ were eluted. After withdrawal of the organic 
A

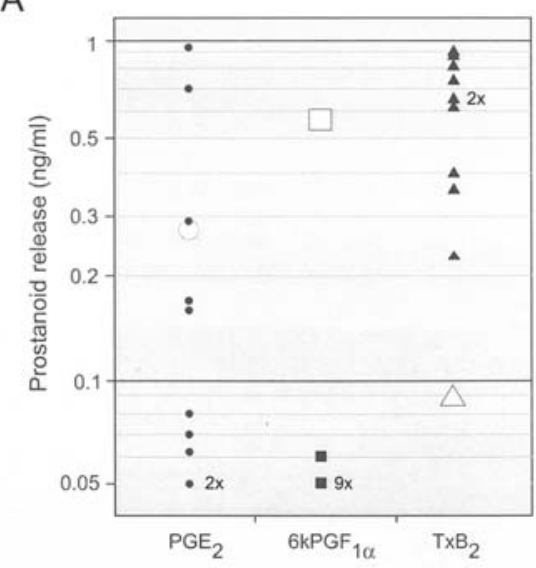

B

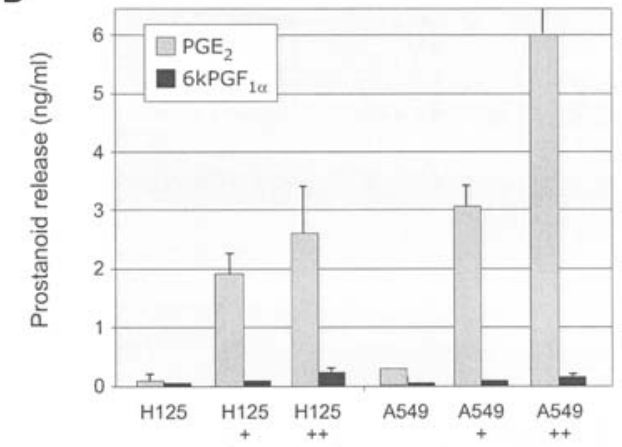

C

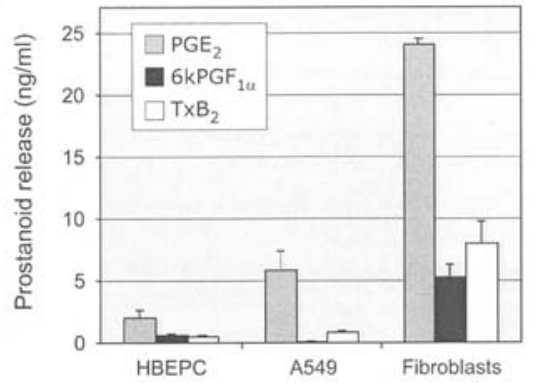

Figure 1. Prostanoid release by human NSCLC cell lines. (A) $\mathrm{PGE}_{2}$, 6-keto$\mathrm{PGF}_{1 \alpha}$ and $\mathrm{TxB}_{2}$ levels in the medium of the 10 different human NSCLC cell lines (filled marks) and normal HBEPCs (open marks) were determined by GC-MS analysis. Data points for $\mathrm{PGE}_{2}$ in NSCLC cell lines (solid circles) from top to bottom (values in $\mathrm{ng} / \mathrm{ml}$ ): H2073 (0.92), A549 (0.7), H596 (0.3), H322 (0.17), H23 (0.15), H125 (0.08), H2347 (0.07), H1373 (0.06), H522

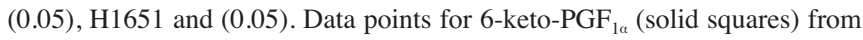
top to bottom: $\mathrm{H} 2073(0.06)$ and all others $(<0.05)$. Data points for $\mathrm{TxB}_{2}$ (solid triangles) from top to bottom: H125 (0.90), H23 (0.88), H596 (0.82), H522 (0.74), H322 (0.66), H2347 (0.65), H1373 (0.62), A549 (0.40), H2073 (0.36), H1651 (0.23). The graphs show the concentration of the indicated prostanoids after culturing $10^{6}$ cells in $5 \mathrm{ml}$ of medium for $24 \mathrm{~h}$. (B) $\mathrm{PGE}_{2}$ and 6-keto-PGF ${ }_{1 \alpha}$ released by human NSCLC cells in the presence of $10 \mu \mathrm{M}$ arachadonic acid $(+)$ or $10 \mu \mathrm{M}$ arachadonic acid $+100 \mathrm{nM}$ TPA $+3 \mu \mathrm{M}$ of the calcium ionophore A23187 (++). (C) Comparison of prostanoid released by normal HBEPCs, A549 NSCLC cells and HEL fibroblasts in the presence of $10 \mu \mathrm{M}$ arachadonic acid.

layers, trimethylsilyl ethers were prepared by reaction with bis(trimethylsilyl)-trifluoroacetamide and thereafter subjected to GC/MS/MS analysis on a Finnigan (Thermo Electron Corp., Dreieich, Germany) MAT TSQ700 GC/MS/MS equipped with a Varian (Palo Alto, CA) 3400 gas chromatograph and a CTC A200S (27).
Immunoblot analysis. Expression of PGIS protein was analyzed by immunoblot analysis using a rabbit polyclonal anti-PGIS antibody as previously described (28). Briefly, $20 \mu \mathrm{g}$ of total cell lysate was separated on $10 \%$ SDS-PAGE, blotted onto nitrocellulose, and probed with the rabbit polyclonal anti-PGIS antibody (diluted 1:500).

\section{Results}

Prostanoid synthesis in human NSCLC cells and fibroblasts. We first measured the synthesis of prostanoids by 10 different human NSCLC cell lines. $\mathrm{PGE}_{2}$ was consistently found in the growth medium of all 10 cell lines tested, albeit at variable levels, with the highest values found for A549, H2073, H596 and H322 cells (Fig. 1A). In contrast, the concentration of 6-keto-PGF ${ }_{1 \alpha}$ (a direct metabolite of, and marker for, the unstable $\mathrm{PGI}_{2}$ ) was very low or undetectable, and in all cases clearly below the biosynthetic rate of normal human bronchial epithelial cells (HBEPCs). In contrast, $\mathrm{TxB}_{2}$, a direct metabolite of $\mathrm{TxA}_{2}$, was released by all NSCLC cell lines at moderate but significantly higher levels compared to HBEPCs. $\mathrm{PGD}_{2}$ was also determined but was very low in all cases including HBEPCs (data not shown). To determine whether the lack of $\mathrm{PGI}_{2}$ synthesis was due to ratelimiting substrate concentrations, we also performed the experiment in the presence of $10 \mu \mathrm{M}$ arachidonic acid (Fig. 1B). However, in contrast to $\mathrm{PGE}_{2}$, no significant effect on the release of 6-keto-PGF ${ }_{1 \alpha}$ was observed. Likewise, the simultaneous stimulation of Cox-2 by the phorbol ester TPA and a calcium ionophore further enhanced $\mathrm{PGE}_{2}$ synthesis in the absence of a significant increase in the release of 6-keto$\mathrm{PGF}_{1 \alpha}$ (Fig. 1B). We also determined prostanoid synthesis in human fibroblasts (HEL; Fig. 1C). As expected, these cells released high levels of $\mathrm{PGE}_{2}, 6$-keto- $\mathrm{PGF}_{1 \alpha}$ and $\mathrm{TxB}_{2}$.

Expression of genes encoding enzymes of prostanoid synthesis and prostanoid receptors. Next, we investigated the expression of the Cox-1 and Cox-2 genes in NSCLC cells in comparison to WI38 lung fibroblasts (Fig. 2A). As expected, Cox-2 was the predominantly expressed subtype observed in all NSCLC cells but H2073 strongly expressed both Cox-1 and $C o x-2$. The levels of Cox-2 mRNA in NSCLC cell lines showed a good correlation with the rate of $\mathrm{PGE}_{2}$ biosynthesis (Fig. 1A). Consistent with the lack of $\mathrm{PGI}_{2}$ synthesis, many of the NSCLC cell lines did not express PGIS at detectable levels, and in those cases where PGIS mRNA was found, PGIS protein was extremely low or undetectable (Fig. 2B). This suggests that NSCLC cells down-regulate the synthesis of $\mathrm{PGI}_{2}$ at multiple levels, including transcriptional and translational mechanism(s). Analysis of the mRNA expression profiles for all known prostanoid membrane receptors showed a high and almost uniform expression for EP1, EP2 and $E P 4$, while expression of $E P 3, I P$ and $T P$ was basically undetectable in the vast majority of the NSCLC cell lines (Fig. 2C). In contrast, EP1, EP2, EP4, IP and TP expression was clearly detectable in human fibroblasts (Fig. 2C).

Prostanoid synthesis in mouse lung tumor cells and fibroblasts. Next, we studied the synthesis of prostanoids by 

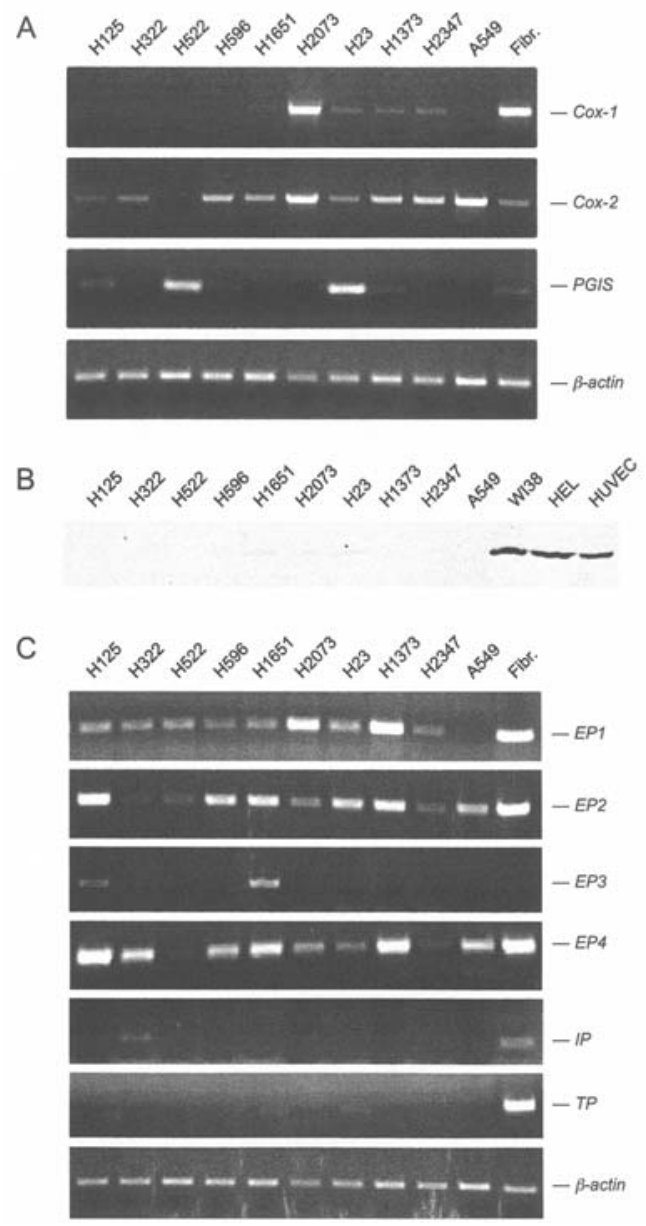

Figure 2. Expression of genes involved in prostanoid biosynthesis and signaling by human NSCLC cell lines. (A) Expression of Cox-1, Cox-2 and PGIS mRNA in human NSCLC cells and WI38 fibroblasts. RNA was extracted from normally cycling cells, and mRNA levels were determined by RT-PCR. $\beta$-actin was included as the standard. (B) Immunoblot analysis of PGIS levels in human NSCLC cell lines, WI38 and HEL fibroblasts and HUVEC. Equal loading was verified by staining for $B$-actin (not shown). (C) Expression of genes coding for prostanoid membrane receptors in human NSCLC cell lines and HEL fibroblasts. RNA was analyzed as in panel D for mRNA levels of $E P 1, E P 2, E P 3, E P 4, I P$ and $T P$.

cell lines derived from mouse lung adenoma and adenocarcinoma (Fig. 3). All four cell lines showed a high rate of $\mathrm{PGE}_{2}$ synthesis, failed to release 6-keto- $\mathrm{PGF}_{1 \alpha}$ at significant levels and showed low but readily detectable levels of $\mathrm{TxB}_{2}$ release. These data are in agreement with our observation made with human lung cancer cell lines, suggesting that these findings are of general relevance to lung adenocarcinomas.

Gene expression patterns in primary human NSCLCs. Finally, we analyzed the expression of PGIS in five matched pairs of human NSCLCs and normal lung tissue to exclude that the lack of $\mathrm{PGI}_{2}$ synthesis observed in NSCLC cell lines is a cell culture artifact. As can be seen in Fig. 4, expression of $P G I S$ mRNA was dramatically reduced in all tumor tissue samples compared to the normal lung (5-10 $\mathrm{Ct}$ values, corresponding to an $\sim 30$ - to 1000 -fold difference). This result is fully compatible with our study of established lung tumor cell lines, and is also in agreement with published immuno-

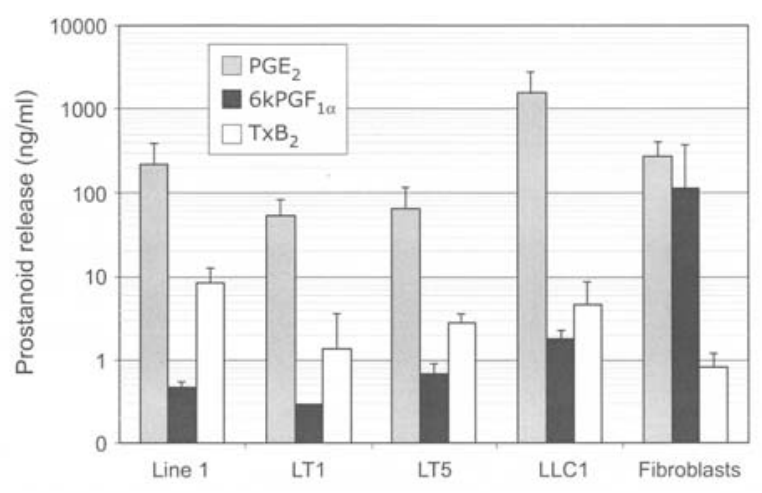

Figure 3. Prostanoid release by mouse lung tumor cell lines and NIH3T3 fibroblasts. The data represent the concentrations of $\mathrm{PGE}_{2}, 6-\mathrm{keto}^{-\mathrm{PGF}_{1 \alpha} \text { and }}$ $\mathrm{TxB}_{2}$ after culturing $10^{6}$ cells in $5 \mathrm{ml}$ of medium for $24 \mathrm{~h}$. Bars represent average values, error bars show the standard deviation.

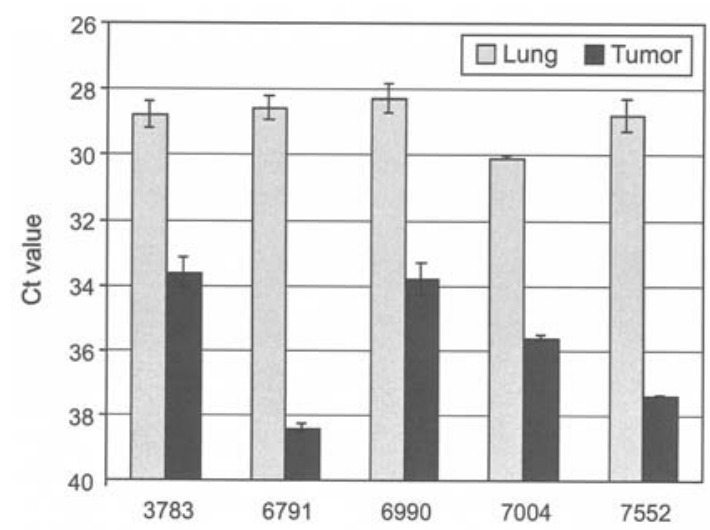

Figure 4. PGIS expression in primary human NSCLCs. PGIS mRNA levels in matched samples of primary human NSCLCs and normal lung tissue from the same patient were analyzed by qPCR. Numbers indicate anonymized patient IDs. Bar graphs in all panels represent average $\mathrm{Ct}$ values (2-5 measurements) and error bars show the standard deviation. L27 was used as the normalizer for all samples.

histochemical observations (25). We also measured $I P$ expression, which was equally low in all tumor and lung tissue samples analyzed $(\mathrm{Ct} \geq 31$; data not shown). This finding is also in agreement with our cell culture data.

\section{Discussion}

A vast body of evidence suggests that the tumor-promoting effects of Cox-2 are attributable to a major extent to overproduction of $\mathrm{PGE}_{2}$ and the ensuing stimulation of $\mathrm{PGE}_{2}$ membrane receptors $(7,8,10,11,9,29-32)$. Particularly strong evidence derived from mouse models exists for EP2 and EP4 in gastrointestinal tumors $(29,30)$ and mammary carcinoma (32). Our findings obtained with human NSCLCs are consistent with this picture and suggest that autocrine/paracrine $\mathrm{PGE}_{2}$ signaling might be of high relevance for these cells. In contrast, $\mathrm{TxA}_{2}$ is synthesized by NSCLCs at appreciable amounts, but NSCLC cells fail to express the gene encoding its receptor, $T P$. On the other hand, fibroblasts strongly express $T P$ and synthesize $\mathrm{TxA}_{2}$, which would be compatible with a role in the growth supporting stroma. Strikingly, 
NSCLC cells do not synthesize $\mathrm{PGI}_{2}$ due to a lack of PGIS and do not express the $\mathrm{PGI}_{2}$ receptor gene, IP. These findings indicate that $\mathrm{PGI}_{2}$-driven signaling pathways are not essential for NSCLC cells, and may even point to a potentially negative effect on tumor growth. This hypothesis is indeed supported by a previous study that showed suppression of lung adenoma growth by the pneumocyte-directed expression of a PGIS transgene in mice (15).

\section{Acknowledgements}

We are grateful to Margitta Alt, Bernhard Wilke and Bernhard Watzer for their excellent technical assistance, and to Dr Thomas Klein (Altana Pharma, Konstanz, Germany) for providing the anti-PGIS antibody. This study was supported by grants from the Wilhelm-Sander-Stiftung and the Deutsche Krebshilfe.

\section{References}

1. Smith WL, DeWitt DL and Garavito RM: Cyclooxygenases: Structural, cellular, and molecular biology. Annu Rev Biochem 69: 145-182, 2000.

2. Williams CS, Mann M and DuBois RN: The role of cyclooxygenases in inflammation, cancer, and development. Oncogene 18: 7908-7916, 1999.

3. Gupta RA and Dubois RN: Colorectal cancer prevention and treatment by inhibition of cyclooxygenase-2. Nat Rev Cancer 1: 11-21, 2001.

4. Dannenberg AJ and Subbaramaiah K: Targeting cyclooxygenase- 2 in human neoplasia: Rationale and promise. Cancer Cell 4: 431-436, 2003.

5. Versteeg HH, van Bergen en Henegouwen PM, van Deventer SJ and Peppelenbosch MP: Cyclooxygenase-dependent signalling: Molecular events and consequences. FEBS Lett 445: 1-5, 1999.

6. Müller R: Crosstalk of oncogenic and prostanoid signaling pathways. J Cancer Res Clin Oncol 130: 429-444, 2004.

7. Sonoshita M, Takaku K, Sasaki N, Sugimoto Y, Ushikubi F, Narumiya S, Oshima M and Taketo MM: Acceleration of intestinal polyposis through prostaglandin receptor ep 2 in apc(delta 716) knockout mice. Nat Med 7: 1048-1051, 2001.

8. Seno H, Oshima M, Ishikawa TO, Oshima H, Takaku K, Chiba T, Narumiya S and Taketo MM: Cyclooxygenase 2- and prostaglandin $\mathrm{e}(2)$ receptor ep(2)-dependent angiogenesis in apc(delta716) mouse intestinal polyps. Cancer Res 62: 506-511, 2002.

9. Mutoh M, Watanabe K, Kitamura T, Shoji Y, Takahashi M, Kawamori T, Tani K, Kobayashi M, Maruyama T, Kobayashi K, Ohuchida S, Sugimoto Y, Narumiya S, Sugimura T and Wakabayashi K: Involvement of prostaglandin e receptor subtype ep(4) in colon carcinogenesis. Cancer Res 62: 28-32, 2002.

10. Yang L, Yamagata N, Yadav R, Brandon S, Courtney RL, Morrow JD, Shyr Y, Boothby M, Joyce S, Carbone DP and Breyer RM: Cancer-associated immunodeficiency and dendritic cell abnormalities mediated by the prostaglandin ep 2 receptor. J Clin Invest 111: 727-735, 2003.

11. Amano H, Hayashi I, Endo H, Kitasato H, Yamashina S, Maruyama T, Kobayashi M, Satoh K, Narita M, Sugimoto Y, Murata T, Yoshimura H, Narumiya S and Majima M: Host prostaglandin e(2)-ep3 signaling regulates tumor-associated angiogenesis and tumor growth. J Exp Med 197: 221-232, 2003.

12. Kitamura T, Itoh M, Noda T, Tani K, Kobayashi M, Maruyama T, Kobayashi K, Ohuchida S, Sugimura T and Wakabayashi K: Combined effects of prostaglandin e receptor subtype ep 1 and subtype ep4 antagonists on intestinal tumorigenesis in adenomatous polyposis coli gene knockout mice. Cancer Sci 94: 618-621, 2003.

13. Kuwano T, Nakao S, Yamamoto H, Tsuneyoshi M, Yamamoto T, Kuwano $\mathrm{M}$ and Ono $\mathrm{M}$ : Cyclooxygenase 2 is a key enzyme for inflammatory cytokine-induced angiogenesis. FASEB J 18: 300-310, 2004.
14. Hatae T, Wada M, Yokoyama C, Shimonishi M and Tanabe T: Prostacyclin-dependent apoptosis mediated by ppar delta. J Biol Chem 276: 46260-46267, 2001.

15. Keith RL, Miller YE, Hoshikawa Y, Moore MD, Gesell TL, Gao B, Malkinson AM, Golpon HA, Nemenoff RA and Geraci MW: Manipulation of pulmonary prostacyclin synthase expression prevents murine lung cancer. Cancer Res 62: 734-740, 2002.

16. Cutler NS, Graves-Deal R, LaFleur BJ, Gao Z, Boman BM, Whitehead RH, Terry E, Morrow JD and Coffey RJ: Stromal production of prostacyclin confers an antiapoptotic effect to colonic epithelial cells. Cancer Res 63: 1748-1751, 2003.

17. Pradono P, Tazawa R, Maemondo M, Tanaka M, Usui K, Saijo Y, Hagiwara K and Nukiwa T: Gene transfer of thromboxane a(2) synthase and prostaglandin $\mathrm{i}(2)$ synthase antithetically altered tumor angiogenesis and tumor growth. Cancer Res 62: 63-66, 2002.

18. Yoshimatsu K, Altorki NK, Golijanin D, Zhang F, Jakobsson PJ, Dannenberg AJ and Subbaramaiah K: Inducible prostaglandin e synthase is overexpressed in non-small cell lung cancer. Clin Cancer Res 7: 2669-2674, 2001.

19. Duperron $\mathrm{C}$ and Castonguay A: Chemopreventive efficacies of aspirin and sulindac against lung tumorigenesis in $\mathrm{a} / \mathrm{j}$ mice. Carcinogenesis 18: 1001-1006, 1997.

20. Rioux N and Castonguay A: Prevention of nnk-induced lung tumorigenesis in $\mathrm{a} / \mathrm{j}$ mice by acetylsalicylic acid and ns-398. Cancer Res 58: 5354-5360, 1998.

21. Yao R, Rioux N, Castonguay A and You M: Inhibition of cox-2 and induction of apoptosis: Two determinants of nonsteroidal anti-inflammatory drugs' chemopreventive efficacies in mouse lung tumorigenesis. Exp Lung Res 26: 731-742, 2000.

22. Moody TW, Leyton J, Zakowicz H, Hida T, Kang Y, Jakowlew S, You L, Ozbun L, Zia H, Youngberg J and Malkinson A: Indomethacin reduces lung adenoma number in $\mathrm{a} / \mathrm{j}$ mice. Anticancer Res 21: 1749-1755, 2001.

23. Eli Y, Przedecki F, Levin G, Kariv N and Raz A: Comparative effects of indomethacin on cell proliferation and cell cycle progression in tumor cells grown in vitro and in vivo. Biochem Pharmacol 61: 565-571, 2001.

24. Hida T, Kozaki K, Ito H, Miyaishi O, Tatematsu Y, Suzuki T, Matsuo K, Sugiura T, Ogawa M and Takahashi T: Significant growth inhibition of human lung cancer cells both in vitro and in vivo by the combined use of a selective cyclooxygenase 2 inhibitor, jte-522, and conventional anticancer agents. Clin Cancer Res 8: 2443-2447, 2002.

25. Ermert L, Dierkes C and Ermert M: Immunohistochemical expression of cyclooxygenase isoenzymes and downstream enzymes in human lung tumors. Clin Cancer Res 9: 1604-1610, 2003.

26. Stoner GD, Hallman M and Troxell MC: Lecithin biosynthesis in a clonal line of lung adenoma cells with type ii alveolar cell properties. Exp Mol Pathol 29: 102-114, 1978.

27. Schweer H, Watzer B and Seyberth HW: Determination of seven prostanoids in $1 \mathrm{ml}$ of urine by gas chromatographynegative ion chemical ionization triple stage quadrupole mass spectrometry. J Chromatogr 652: 221-227, 1994.

28. Siegle I, Klein T, Zou MH, Fritz P and Komhoff M: Distribution and cellular localization of prostacyclin synthase in human brain. J Histochem Cytochem 48: 631-641, 2000.

29. Asano T, Shoda J, Ueda T, Kawamoto T, Todoroki T, Shimonishi M, Tanabe T, Sugimoto Y, Ichikawa A, Mutoh M, Tanaka $\mathrm{N}$ and Miwa M: Expressions of cyclooxygenase-2 and prostaglandin e-receptors in carcinoma of the gallbladder: Crucial role of arachidonate metabolism in tumor growth and progression. Clin Cancer Res 8: 1157-1167, 2002.

30. Pozzi A, Yan X, Macias-Perez I, Wei S, Hata AN, Breyer RM, Morrow JD and Capdevila JH: Colon carcinoma cell growth is associated with prostaglandin e2/ep4 receptor-evoked erk activation. J Biol Chem 279: 29797-29804, 2004.

31. Chell SD, Witherden IR, Dobson RR, Moorghen M, Herman AA, Qualtrough D, Williams AC and Paraskeva C: Increased ep4 receptor expression in colorectal cancer progression promotes cell growth and anchorage independence. Cancer Res 66: 3106-3113, 2006 .

32. Ma X, Kundu N, Rifat S, Walser T and Fulton AM: Prostaglandin e receptor ep4 antagonism inhibits breast cancer metastasis. Cancer Res 66: 2923-2927, 2006. 